\title{
Optimized Production and Characterization of $\beta$-fructofuranosidase from Penicillium brevicompactum
}

\author{
C.Uma*, D Gomathi, C Muthulakshmi, G Ravikumar and V K Gopalakrishnan \\ Department of Biochemistry, Karpagam University, Coimbatore, India
}

(Received 12 January 2011; Accepted 14 July 2011)

\begin{abstract}
The present study is aimed at the optimization of $\beta$-fructofuranosidase from Penicillium brevicompactum using orange fruit peel waste as a substrate in Czapek Dox as basal medium by submerged fermentation (SmF). The optimum $\mathrm{pH}$, temperature and incubation period for enzyme production were $5,30^{\circ} \mathrm{C}$ and $4^{\text {th }}$ day respectively. Of the carbon source, sucrose was recorded to be the best carbon source for enzyme production yeast extract was ideal nitrogen source for the $\beta$-fructofuranosidase production. The enzyme was purified to 5.8 fold with recovery of $3.2 \%$ by DEAE-column chromatography and the molecular weight was estimated to be $64 \mathrm{KDa}$ by SDS-PAGE. It has a $V_{\max }$ value of $15.8 \mathrm{U} / \mathrm{mg}$ and $K_{\mathrm{m}}$ value of $0.23 \mathrm{mg} / \mathrm{ml}$ at $\mathrm{pH}$. The enzyme activity was found to be stable at $50^{\circ} \mathrm{C}$ for 30 minutes and it was stimulated by metal ions like $\mathrm{Na}^{+}$and $\mathrm{Ca}^{2+}$ and inhibited by Zinc. These results highlight the industrial potentials of the substrates as possible raw materials for $\beta$-fructofuranosidase enzyme production from Penicillium brevicompactum.
\end{abstract}

Keywords: $\beta$-fructofuranosidase, Penicillium brevicompactum, Fruit peel waste, Optimization.

\section{Introduction}

$\beta$-fructofuranosidase is a special kind of enzyme which catalysis the hydrolysis of terminal non-reducing â-fructofuranoside residue in sucrose. The enzyme has wide range of commercial applications including the production of confectionery with liquid or soft centers, chocolates and fermentation of cane molasses into ethanol. $\beta$-fructofuranosidase is also used in pharmaceutical industry as digestive aid tablets, powder milk for infants' foods, as calf feed preparation, assimilation of alcohol in fortified wines and in manufacture of inverted sugars as food for honeybees ${ }^{1}$.

$\beta$-fructofuranosidase is used for the inversion of sucrose in the preparation of invert sugar and high fructose syrup (HFS). It is one of the most widely used enzymes in food industry where fructose is preferred than sucrose especially in the preparation of jams and candies, because it is sweeter and does not crystallize easily ${ }^{2}$. The enzymatic activity of â-fructofuranosidase has been characterized mainly in plants and microorganisms. Among microorganisms, Saccharomyces cerevisae ${ }^{3}$, Candida utilis ${ }^{4}$, Aspergillus niger ${ }^{5}$, Thermomyces lanuginosus ${ }^{6}$ and Penicillium chrisogenum ${ }^{7}$ has been widely studied.

$\beta$-fructofuranosidase exhibits marked stability towards temperature, $\mathrm{pH}$ changes and denaturants. Temperature of the reaction mixture determines the rate of sucrose inversion by the active enzyme ${ }^{8}$. The present study is aimed at the optimization of culture conditions for the enhanced production of $\beta$ - fructofuranosidase from Penicillium brevicompactum using fruit peel waste as cheap substrate has been carried out which has good potential for biotechnological applications.

\section{Materials and methods}

Organism and inoculum preparation

Fungal strains were isolated from the soil of sugarcane field Coimbatore, India by dilution plate method. The culture was screened for $\beta$-fructofuranosidase enzyme production. The fungal strain Penicillium brevicompactum was selected for the production of $\beta$-fructofuranosidase and it was prepared from 4 days old slant culture.

\section{Fermentation condition}

The medium used for the enzyme production under submerged fermentation was comprised of $(\mathrm{g} / \mathrm{l})$ : sucrose 20 , yeast extract 10 , ammonium sulphate 1.0 , magnesium sulphate 0.75 , potassium dihydrogen phosphate 3.5 , and $\mathrm{pH}$ 5.0. Cultivation was carried out in $250 \mathrm{ml}$ Erlenmeyer flasks each containing $50 \mathrm{ml}$ of sterile medium. Instead of sucrose, orange peel waste was substituted in the present study. After inoculation $\left(10^{6} \mathrm{spores} / \mathrm{ml}\right)$, the flasks were incubated at $30^{\circ} \mathrm{C}$ for seven days in an incubator shaker at $125 \mathrm{rpm}$. At the end of fermentation, the supernatant was harvested by centrifugation at $10,000 \mathrm{rpm}$ for $10 \mathrm{~min}\left(4^{\circ} \mathrm{C}\right)$ and was used as crude enzyme extract. The substrate (orange peel) was fed with varying sizes of inoculum of the organism. The

*Corresponding author

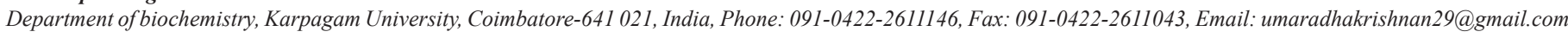


inoculum size was varied from 1.0 to $5.0 \%$ and the enzyme activity was measured every 24 hours.

Enzyme assay

$\beta$-fructofuranosidase activity was determined using the method of Sumner and Howells ${ }^{9}$ with slight modification by incubating $0.1 \mathrm{ml}$ of enzyme solution with $0.9 \mathrm{ml}$ of sucrose in $0.03 \mathrm{M}$ acetate buffer ( $\mathrm{pH}$ 5.0). To stop the reaction, $1 \mathrm{ml}$ of dinitrosalicylic acid reagent was added and heated for $5 \mathrm{~min}$ in a boiling water bath. Finally the absorbance was read at $540 \mathrm{~nm}$ in spectrophotometer ${ }^{10}$. One unit of $\beta$-fructofuranosidase (IU) is defined as the amount of enzyme which liberates 1 ì moles of glucose/minute/ml under the assay condition.

The optimization of the culture condition and the effects of various factors like inoculum size, carbon sources, nitrogen sources, $\mathrm{pH}$ and temperature on the production of $\beta$ fructofuranosidase were studied.

\section{Purification and characterization of $\beta$-fructofuranosidase}

Crude extract $(100 \mathrm{ml})$ was precipitated by $70 \%$ saturation with ammonium sulphate and then dialyzed against $100 \mathrm{mM}$ Tris phosphate buffer $(\mathrm{pH} 7.5)$ for 24 hours at $4^{0} \mathrm{C}$. The filtrate was loaded onto a DEAE-cellulose chromatographic column $(25 \mathrm{~cm}$ * $2.6 \mathrm{~cm}$ ) equilibrated with Tris-HCl buffer, $100 \mathrm{mM}$, and $\mathrm{pH}$ 7.5. The enzyme was eluted with a linear salt concentration gradient $(\mathrm{NaCl}$, 0-0.4 M) in the same buffer and $3.0 \mathrm{ml}$ fractions were collected at a flow rate of $20 \mathrm{ml}$ per hour.

SDS-PAGE electrophoresis was carried out and molecular weight was determined. The protein content was estimated by the method of Lowry ${ }^{11}$. The kinetic parameter of the purified $\beta$ fructofuranosidase enzyme was determined and the optimum $\mathrm{pH}$ and temperature on the activity of the enzyme were also assayed. All experiments were conducted with triplicates and their mean values are represented.

\section{Results}

The optimization of fermentation medium was done by measuring the enzyme activity by varying the single parameter such as $\mathrm{pH}$, temperature, inoculum size, carbon, nitrogen and substrate concentration of the medium while keeping the remaining parameter unaltered. The highest level of extractellular $\beta$ fructofuranosidase was obtained in Czapek Dox medium using fruit peel waste under orbital agitation $(125 \mathrm{rpm})$ at $30^{\circ} \mathrm{C}$ for seven days.

The selected substrates (Orange, Pineapple, and Pomegranate) were analyzed for carbon and nitrogen content in CHNS analyzer and it was found that $\mathrm{C}: \mathrm{N}$ ratio was higher in the case of orange peel when compared to other two substrates pomegranate and pineapple (Fig. 1). Different concentrations (1-5\%) of the selected substrates were studied and $4 \%$ of the substrates produced better results of enzyme production (Fig. 2). Hence further experiments were carried out with orange peel as the substrate.

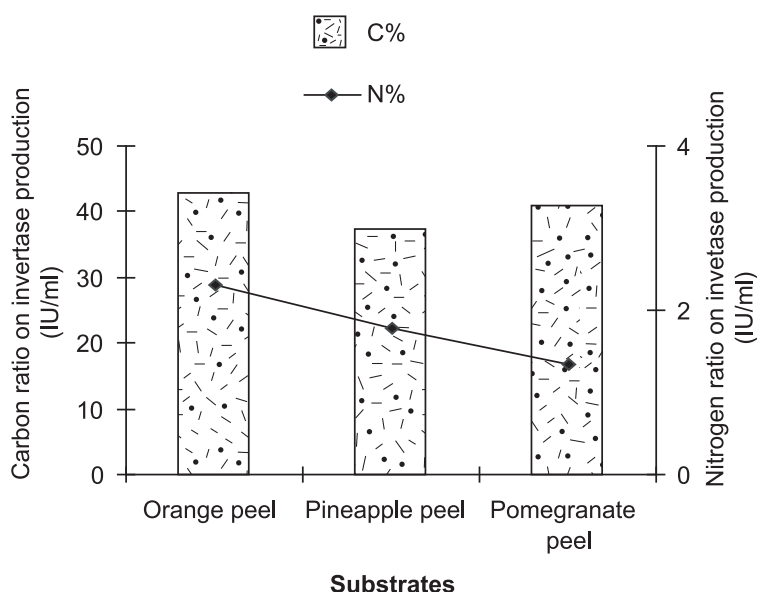

Figure 1. Carbon and Nitrogen content of the fruit peel waste as substrate using CHNS analyzer.

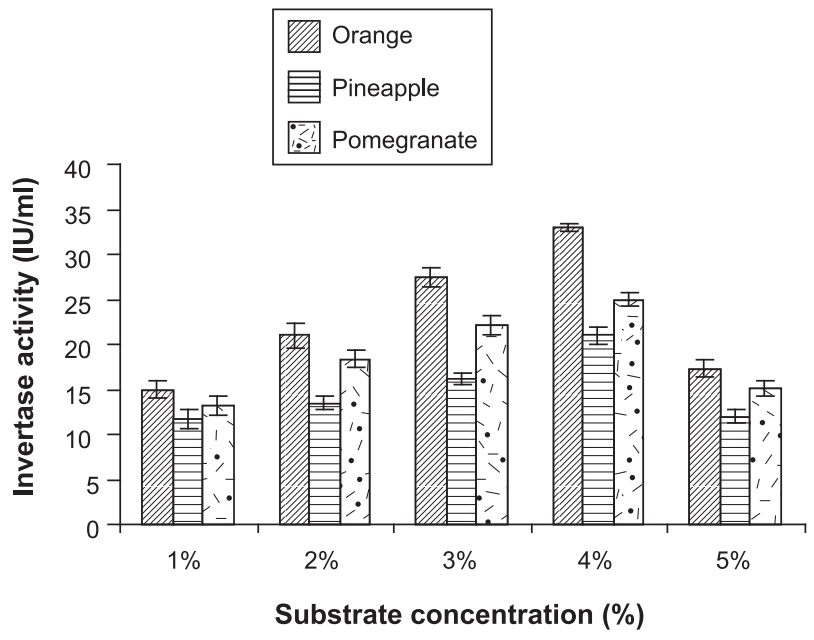

Figure 2. Effect of different concentration (1-5\%) of fruit peel waste as substrate on $\beta$-fructofuranosidase production by $P$. brevicompactum. Results are mean of three independent determinations. Bars correspond to standard deviation.

The enzyme activity was measured at regular intervals of $24 \mathrm{hrs}$ at $\mathrm{pH} 3-8$ and with varying temperature $20-60^{\circ} \mathrm{C}$. The maximum enzyme production occurred at $3 \%$ of inoculum size was $25.0 \mathrm{IU} /$ $\mathrm{ml}$ at $\mathrm{pH} 5$ and kept at $30^{\circ} \mathrm{C}$ when orange peel was used as substrate (Table 1).

The effect of different carbon (fructose, glucose, lactose, rafinose and sucrose) and nitrogen sources (peptone, urea and yeast) were tested by incorporating $1 \%$ of the above set sources into fermentation medium. Production was more pronounced by the addition of sucrose and yeast extract as the nutritional factors (Table 1). 
Table 1. Effects of various factors on â-fructofuranosidase production from P. brevicompactum

\begin{tabular}{|c|c|c|c|c|c|c|}
\hline \multirow[t]{2}{*}{ Factors } & \multicolumn{6}{|c|}{$\beta$-fructofuranosidase production (IU/ml) Incubation days (hours) } \\
\hline & 24 & 48 & 72 & 96 & 120 & 144 \\
\hline \multicolumn{7}{|l|}{$\mathrm{pH}$} \\
\hline 3 & 4.8 & 8.5 & 11.1 & 12.5 & 10.3 & 7.6 \\
\hline 4 & 6.2 & 9.1 & 13.4 & 16.8 & 12.9 & 9.2 \\
\hline 5 & 10.5 & 14.6 & 19.2 & 23.8 & 19.7 & 14.3 \\
\hline 6 & 5.6 & 7.2 & 12.6 & 19.5 & 15.2 & 10.1 \\
\hline 7 & 3.2 & 5.7 & 7.2 & 10.4 & 8.3 & 5.8 \\
\hline 8 & 2.9 & 4.2 & 6.0 & 7.9 & 5.2 & 3.2 \\
\hline \multicolumn{7}{|c|}{ Temperature $\left({ }^{\circ} \mathrm{C}\right)$} \\
\hline 20 & 10.2 & 14.6 & 16.2 & 18.6 & 17.0 & 12.2 \\
\hline 30 & 15.2 & 23.3 & 26.8 & 28.8 & 20.6 & 14.0 \\
\hline 40 & 10.9 & 17.6 & 19.9 & 21.6 & 17.3 & 11.1 \\
\hline 50 & 9.9 & 14.9 & 16.1 & 17.8 & 15.0 & 13.3 \\
\hline 60 & 11.9 & 12.6 & 14.0 & 15.3 & 12.3 & 7.3 \\
\hline \multicolumn{7}{|c|}{ Inoculum size (\%) } \\
\hline 1 & 5.8 & 9.5 & 10.5 & 15.0 & 13.4 & 7.5 \\
\hline 2 & 8.9 & 11.7 & 15.6 & 20.0 & 12.5 & 8.4 \\
\hline 3 & 9.6 & 12.9 & 18.2 & 25.0 & 17.6 & 11.2 \\
\hline 4 & 7.4 & 9.1 & 12.3 & 18.4 & 11.8 & 5.4 \\
\hline 5 & 4.9 & 7.0 & 10.8 & 14.1 & 9.2 & 4.2 \\
\hline \multicolumn{7}{|c|}{ Carbon Source (g/100mL) } \\
\hline Fructose & 14.3 & 16.2 & 19.3 & 23.9 & 19.8 & 13.3 \\
\hline Glucose & 9.6 & 11.5 & 15.5 & 18.7 & 14.2 & 7.9 \\
\hline Lactose & 11.3 & 14.2 & 16.3 & 20.3 & 11.3 & 6.7 \\
\hline Rafinose & 6.1 & 9.5 & 11.4 & 14.6 & 7.4 & 5.3 \\
\hline Sucrose & 9.3 & 11.2 & 20.1 & 25.6 & 20.3 & 10.6 \\
\hline \multicolumn{7}{|c|}{ Nitrogen Source $(\mathrm{g} / 100 \mathrm{~mL})$} \\
\hline Nutrient broth & 10.6 & 14.6 & 16.6 & 19.0 & 17.7 & 11.6 \\
\hline Peptone & 14.6 & 21.3 & 23.9 & 25.0 & 23.1 & 19.6 \\
\hline Urea & 19.9 & 26.6 & 30.3 & 33.0 & 30.4 & 25.3 \\
\hline Yeast Extract & 18.6 & 26.6 & 29.9 & 33.7 & 31.2 & 24.3 \\
\hline
\end{tabular}

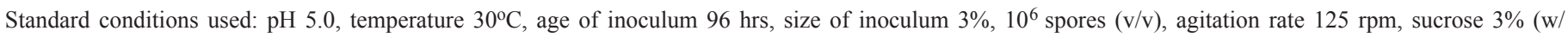
v) and yeast extract.

\section{Purification}

The purification of â-fructofuranosidase from Penicillium brevicompactum has been shown in Table 2 . The specific activity of the final purified preparation was $211.0 \mathrm{U}$ representing a total purification factor of 7.85 .
The elution profiles from DEAE Sephdex A-50 chromatographic column, from which a homogeneous enzyme was eluted with a linear gradient of $(0-0.4 \mathrm{M}) \mathrm{NaCl}$, showed a single peak with a symmetrical distribution of activity. The SDS-PAGE of the enzyme revealed a single protein band, whose estimated molecular weight was $64 \mathrm{KDa}$ (Fig. 3). 
Table 2. Purification and recovery of $\beta$-fructofuranosidase from P. brevicompactum

\begin{tabular}{|c|c|c|c|c|c|}
\hline Steps & $\begin{array}{c}\text { ß-fructofuranosidase } \\
\text { Activity }(\mathrm{U})\end{array}$ & $\begin{array}{c}\text { Total protein } \\
(\mathrm{mg})\end{array}$ & $\begin{array}{c}\text { Specific Activity } \\
(\mathrm{U} / \mathrm{mg})\end{array}$ & Purification (fold) & $\begin{array}{c}\text { Recovery } \\
(\%)\end{array}$ \\
\hline Crude extract & 9970 & 369.45 & 27 & 1 & 100 \\
\hline Dialysis & 511.2 & 9.80 & 52.1 & 1.93 & 5.12 \\
\hline $\begin{array}{l}\text { DEAE Cellulose Column } \\
\text { Chromatography }\end{array}$ & 424.25 & 2.01 & 211.0 & 7.85 & 4.25 \\
\hline
\end{tabular}

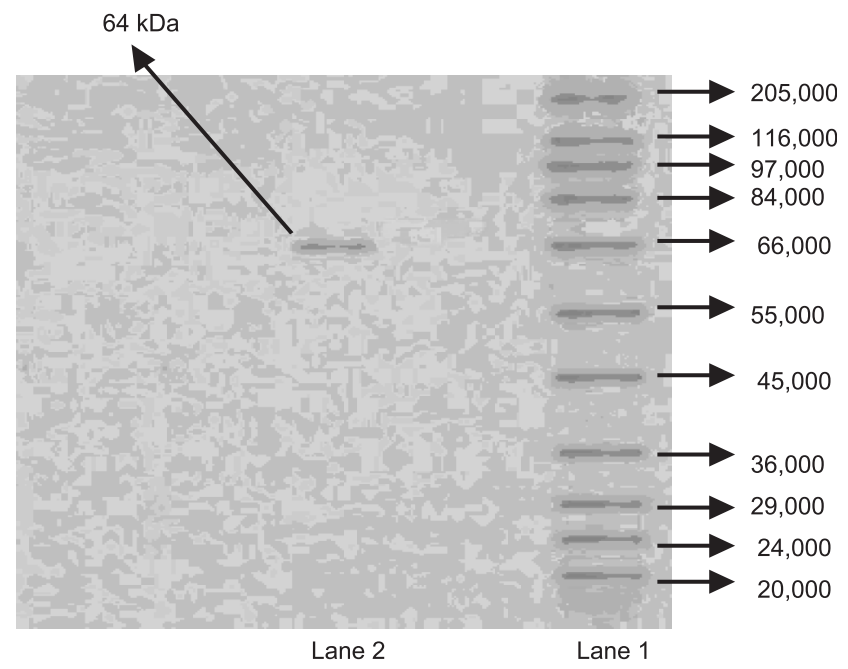

Figure 3. SDS-Polyacrylamide gel electrophoresis of purified $\hat{a}$-fructofuranosidase from P. brevicompactum. Lane 1: Molecular weight marker; Lane 2: Molecular weight of $\hat{a}$ fructofuranosidase

The activity of the enzyme â-fructofuranosidase from Penicillium brevicompactum was stable exhibited a relative broad $\mathrm{pH}$ 5-7 with an optimum $\mathrm{pH}$ of 6.0 (Fig. 4a) and it was found to exhibit maximum activity at $50^{\circ} \mathrm{C}$ with a slight change of stability at $70^{\circ} \mathrm{C}$ (Fig. $4 \mathrm{~b}$ ).
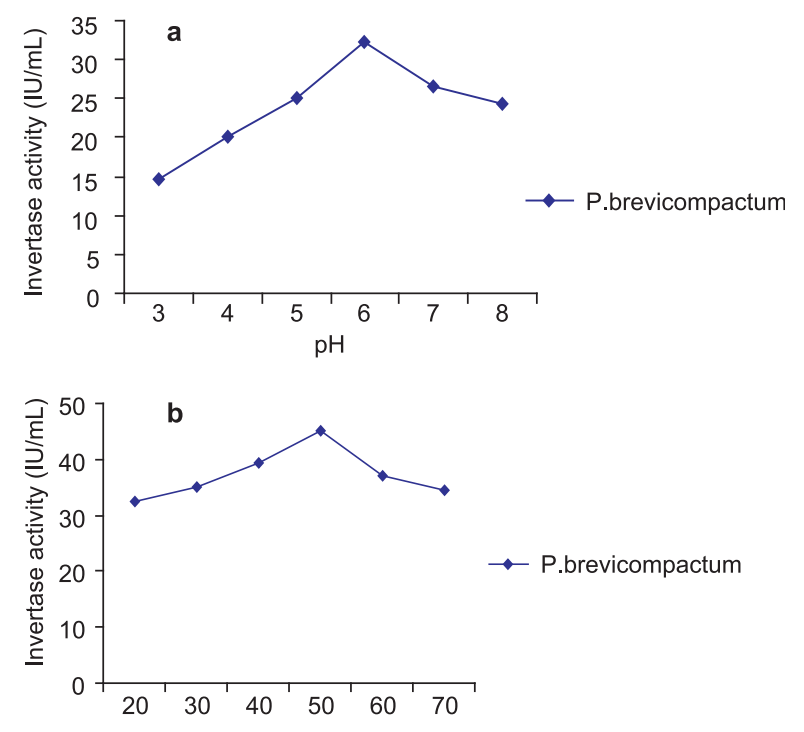

Figure $4 \mathbf{a}$ and $\mathbf{4 b}$. Stability and optimum activities of the enzyme $\hat{a}$-fructofuranosidase at different $\mathrm{pH}$ and temperature from $\mathrm{P}$. brevicompactum.
The kinetic parameters for purified extracellular $\beta$ fructofuranosidase activity were determined using sucrose, in the concentration range of $0.2-1.0 \mathrm{mM}$. The values of $\mathrm{Km}$ and Vmax were calculated by Linewaver Burk plot (Fig. 5).

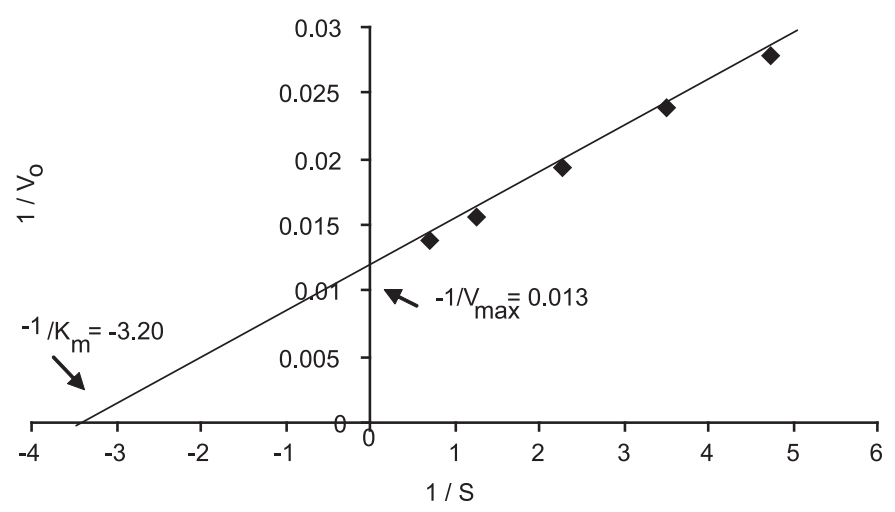

Figure 5. Enzyme kinetics of P. brevicompactum. A LineweaverBurk plot of initial velocity against sucrose concentration. The values are means of three experiments done in duplicate.

It can be seen from the Fig. 6 , that the metal ions $\mathrm{Na}^{+}$and $\mathrm{Ca}^{2+}$ supported the maximum enzyme activity whereas $\mathrm{Zn}^{2+}$ was found to be inhibitor of the enzyme $\beta$-fructofuranosidase.

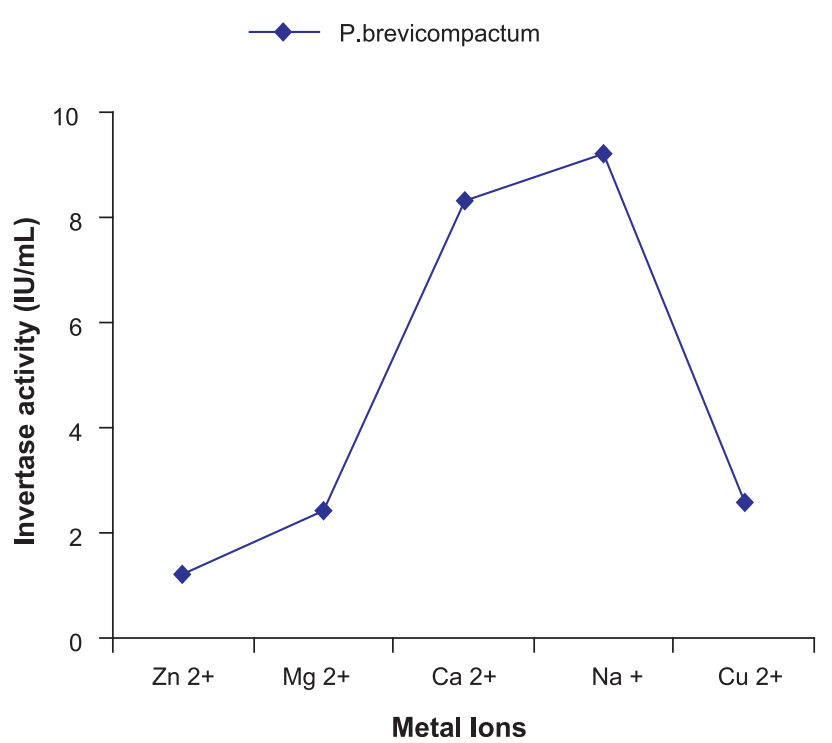

Figure 6. The effect of metal ions $(0.05 M)$ on activity of $\beta$ fructofuranosidase by $P$. brevicompactum. 


\section{Discussion}

Increasing the potential of $\beta$-fructofuranosidase application prompt screening for newer $\beta$-fructofuranosidase producing microorganisms, hence the present production and characterization of $\beta$-fructofuranosidase by $P$. brevicompactum was studied in shake flask culture technique by inoculating $10^{6}$ spores $/ \mathrm{ml}$ of fermentation medium containing the fruit peel waste as substrate.

Optimization of medium composition is one of the essential steps to maintain a balance between the various medium components to minimize the amount of unutilized components at the end of fermentation and have cost-effective metabolite yield ${ }^{12,13}$. Medium components such as nitrogen and carbon sources, physiological factors such as $\mathrm{pH}$, temperature, incubation time and biological factors such as genetic nature of the organism influences the metabolic and chemical behavior of the microbial strain and subsequent metabolite production pattern ${ }^{12}, 13$.

Quantity of inoculum had a definite effect on $\beta$-fructofuranosidase titers. Increase in quantity of the inoculum increased $\beta$ fructofuranosidase titers $25 \%$ of inoculum gave the highest titre in 72 hours at $\mathrm{pH} 5^{13}$. The maximum enzyme production occurred at $4 \%$ of inoculum size was $25.8 \mathrm{IU} / \mathrm{ml}$ at pH 5 at $30^{\circ} \mathrm{C}$ at 96 hours of incubation. Similar report was observed by Guimaraes ${ }^{14}$ who reported the highest level of enzyme production at $40^{\circ} \mathrm{C}$ at 96 hours, where as Shafiq ${ }^{15}$ reported an optimum temperature of $25^{\circ} \mathrm{C}$ for $\beta$-fructofuranosidase production by Saccharomyces cerevisiae GCB-K5. A high level of $\beta$-fructofuranosidase was produced by Penicillium brevicompactum when sucrose was used as a carbon source and yeast extract was used as the nitrogen source. Maximum enzyme activity was found at sucrose concentration of $30.0 \mathrm{~g} / \mathrm{L}$ by Saccharomyces species GCA-II ${ }^{16}$. Different organic nitrogen sources and their concentrations have a major effect on the ability of yeast to synthesize $\beta$ fructofuranosidase ${ }^{17}$.

Our result was in consonance with the work of Guimaraes ${ }^{14}$ who purified the enzyme to 7.1 fold with a recovery of $24 \%$, by two chromatographic steps in DEAE-cellulose and sephacryl s-200, in Aspergillus ochraceus.

The relative activity of the enzyme was retained between $\mathrm{pH} 5$ and 7 whereas Rubio ${ }^{18}$ reported 4.5 as optimum for Rhodortorula glutinis while its half-life was 30 minutes when assayed between $20-70^{\circ} \mathrm{C}$. The stability was higher than that exhibited by the âfructofuranosidase from Azotobacter chroococcum, whose halflife at $60^{\circ} \mathrm{C}$ was 3 minutes $^{14}$. Stability decreased to $50 \%$ when temperature increased to $70^{\circ} \mathrm{C}$.

A Lineweaver-Burk plot of the enzyme affinity for sucrose gave a straight line plot from which the $\mathrm{Km}$ as $0.32 \mathrm{mg} / \mathrm{ml}$ and Vmax was
$74.64 \mathrm{U} / \mathrm{mg}$. The values were similar to that obtained with the $\beta$ fructofuranosidase from Rhodortorula glutinis ${ }^{18}$.

The activity of the enzyme $\beta$-fructofuranosidase was accelerated by the addition of metal ions like $\mathrm{Na}^{+}$and $\mathrm{Ca}^{2+}$. Similar observation was seen from Rhodortorula glutinis, which was activated by $\mathrm{Na}^{+}$and $\mathrm{Mg}^{2+14}$. This result suggests that the metal ions protect the enzyme against thermal denaturation at high temperatures ${ }^{14}$.

$\beta$-fructofuranosidase production by Penicillium brevicompactum under optimized cultural condition where studied and the enzyme was purified to 7.85 fold. The behavior of $\beta$-fructofuranosidase activity at different temperature, $\mathrm{pH}$, substrate concentration were analyzed and it showed good stability at $\mathrm{pH} 6.0$ and temperature $50^{\circ} \mathrm{C}$. Moreover agro wastes are used as substrate for enzyme production which substantially lowers the cost of production qualifying it for application in sucrose hydrolysis and fructose syrup production.

From the present study, we could see that parameters like $\mathrm{pH}$, temperature, substrate concentration, carbon and nitrogen source had different effect in the enzyme production. It can be concluded that the orange peel waste can be more effectively used as a substrate for the production of enzyme under optimized culture conditions. The yield of the enzyme was greatly enhanced when the fungi was grown in shaken flask condition supplemented with sucrose and yeast extract.

\section{Acknowledgement}

The authors thank the Management of Karpagam University for providing lab facilities and constant encouragement for this research work.

\section{References}

1. Chou CC and Jasovsky GA. 1993. Advantages of Escorb TM precoats in liquid sugar production. Int Sugar Journal. 95 (1138): 425-430.

2. Aranda C, Robledo A, Loera O, Juan C, Esquivel C, Rodrigueq R \& Aguillar CN. 2006. Fungal â-fructofuranosidase expression in solid state fermentation. Food Technol Biotechnol. 44(2): 229-233.

3. Herwig C, Doerries C, Marison I and Von Stockar U. 2001. Quantitative analysis of the regulation scheme of â-fructofuranosidase expression in Saccharomyces cerevisiae. Biotechnol Bioeng. 75: 24758.

4. Belcarz A, Ginalska G and Penel C. 2002. The novel non glycosylated â-fructofuranosidase from Candida utilis. J. Biochem and Biophys Acta. 1594: 40-53

5. Romero-Gomez S, Augur C and Viniegra-Gonzalez G. 2000. â fructofuranosidase production by Aspergillus níger in submerged and solid-state fermentation. Biotechnol. Lett. 22: 1255-1258.

6. Chaudhuri A and Maheswari R. 1996. A novel â-fructofuranosidase from a thermophilic fungus Thermomyces lanuginosus: it requirement of tilo and protein for activation. Arch Biochem Biophys .327(1): 98-106.

7. Nuero OM and Reyes F. 2002. Enzymes for animal feeding from Penicillium chrysogenum mycelial wastes from Penicillum manufacture. Lett Appl Microbiol 34: 413-416. 
8. Vrabel P, Polakovic M, Stefuca V and Bales V. 1997. Enzyme Microb Technol. 20: 348-354.

9. Sumner JB and Howell SF. 1935. A method for determination of saccharase activity. $J$ Biol Chem.108: 51-54.

10. Miller GL. 1959. Use of dinitrosalicylic reagent for determination of reducing sugars. Anal Chem. 31: 426-428.

11. Lowry OH, Rosenbrough NJ, Farr AL \& Randall RJ. 1951. Protein measurements with the folin phenol reagent. J Biochem. 193: 265275 .

12. Kumar CG and Takagi H. 1999. Microbial alkaline proteases from a bio industrial view point. Biotechnol Adv. 17: 561-594.

13. Prakasham RSl, Subba Rao CH, Sreenivas Rao R, Rajesham S and Sarma PN. 2005. Optimisation alkaline protease production by Bacillus sp using Taguchi methodology. Appl Biochem Biotechnol. 120: 133-144.
14. Guimaraes LHS, Terenzi HF, Maria De Lourdes \& Jorge JA. 2007. Production and characterization of thermo stable extra cellular âfructofuranosidase produced by Aspergillus ochraceus with agro industrial residues as carbon sources. J Enzyme and Microbial Technol. 42: 52-57.

15. Shafiq K, Ali S and Haq I. 2003. Time course study for yeast âfructofuranosidase production by submerged fermentation. $J$ bacteriol. 3: $984-988$.

16. Baig MA, Shafiq K, Ali S and Haq IU. 2003. Effect of nitrogen and phosphorus on the biosynthesis of â-fructofuranosidase. J Biol Sci. 3: 591-595.

17. Nakano H, Murakami H, Shizuma M, Kiso T, DeAraujo TL and Kitahata. 2000. Transfructosylation of thiol group by betafructofuranosidase. Biosci. Biotechnol. 64: 1472-1476.

18. Rubio MC, Rosa Runco and Navarro AR. 2002. Phytochemistry. 61: 605-609. 